\title{
Sulfur and Zinc Availability from Co-granulated Zn-Enriched Elemental Sulfur Fertilizers
}

\author{
Edson M. Mattiello, ${ }^{* \dagger}$, Rodrigo C. da Silva, ${ }^{\S}$ Fien Degryse, ${ }^{\S}$ Roslyn Baird, ${ }^{\S}$ Vadakattu V. S. R. Gupta, \\ and Michael J. McLaughlin ${ }^{\S, \#}$ \\ ${ }^{\dagger}$ Department of Soil Science, Universidade Federal de Viçosa, Viçosa, Minas Gerais 36570-900, Brazil \\ ${ }^{\S}$ School of Agriculture, Food and Wine, The University of Adelaide, PMB 1, Waite Campus, Glen Osmond, SA 5064, Australia \\ ${ }^{\perp}$ CSIRO Agriculture and Food, PMB 2, Glen Osmond, SA 5064, Australia \\ ${ }^{\#}$ CSIRO Land and Water, PMB 2, Glen Osmond, SA 5064, Australia
}

ABSTRACT: Acidification by oxidation of elemental sulfur (ES) can solubilize ZnO, providing slow release of both sulfur (S) and zinc $(\mathrm{Zn})$ in soil. For this study, a new granular fertilizer with ES and $\mathrm{ZnO}$ was produced and evaluated. The effect of incorporating microorganisms or a carbon source in the granule was also evaluated. Four granulated ES-Zn fertilizers with and without S-oxidizing microorganisms, a commercial ES pastille, $\mathrm{ZnSO}_{4}$, and $\mathrm{ZnO}$ were applied to the center of Petri dishes containing two contrasting $\mathrm{pH}$ soils. Soil $\mathrm{pH}, \mathrm{CaCl}_{2}$-extractable $\mathrm{S}$ and $\mathrm{Zn}$, and remaining ES were evaluated at 30 and 60 days in two soil sections (0-5 and 5-9 $\mathrm{mm}$ from the fertilizer application site). A visualization test was performed to evaluate $\mathrm{Zn}$ diffusion over time. A significant $\mathrm{pH}$ decrease was observed in the acidic soil for all ES- $\mathrm{Zn}$ fertilizer treatments and in the alkaline soil for the Acidithiobacillus thiooxidans-inoculated treatment only. In agreement with $\mathrm{Zn}$ visualization tests, extractable$\mathrm{Zn}$ concentrations were higher from the point of application in the acidic $\left(62.9 \mathrm{mg} \mathrm{dm}^{-3}\right)$ compared to the alkaline soil (5.5 mg $\left.\mathrm{dm}^{-3}\right)$. Elemental $\mathrm{S}$ oxidation was greater in the acidic soil $(20.9 \%)$ than slightly alkaline soil (12\%). The ES-Zn granular fertilizers increased $\mathrm{S}$ and $\mathrm{Zn}$ concentrations in soil and can provide a strategically slow release of nutrients to the soil.

KEYWORDS: Aspergillus niger, Acidithiobacillus thiooxidans, sulfur oxidation, $\mathrm{ZnO}$, micronutrients, $\mathrm{Zn}$ diffusion

\section{INTRODUCTION}

Sulfur (S) and zinc $(\mathrm{Zn})$ deficiencies in soils are common nutrient problems throughout the world, with respect to both crop productivity and human nutrition. ${ }^{1-3}$ Zinc deficiency is widespread and most common in calcareous and sandy soils. ${ }^{4-6}$ Sulfur deficiency has become more prevalent in the past decades due to a decrease in incidental inputs through atmospheric deposition and fertilizers and an increase in crop $\mathrm{S}$ removals. Therefore, $\mathrm{S}$ - and $\mathrm{Zn}$-containing fertilizers are applied to large agricultural areas to increase crop yields and food quality. For $S$ fertilization, gypsum, ammonium sulfate, and elemental S (ES) are the most common sources, whereas $\mathrm{Zn}$ is provided mainly as zinc sulfate or zinc oxide. Although ES is unavailable for plant uptake, it is oxidized in the soil to its plant-available form, $\mathrm{SO}_{4}{ }^{2-}-\mathrm{S}$.

The oxidation of ES in soils occurs quickly if finely divided ES is mixed through soil. ${ }^{7,8}$ However, finely divided ES tends to have a high production cost and can pose a fire or explosion hazard during handling. ${ }^{9}$ Furthermore, applying fine ES particles to soil is impractical using current farmer fertilizer application practices, and mixing it with soil is not compatible with no-tillage practices. As $S^{0}$ oxidation is a biological process, soil properties that affect microbial abundance and activity also affect the oxidation rate. For instance, oxidation of ES was found to be positively correlated with $\mathrm{pH}$, organic matter (OM) content, microbial populations, and activity of soil. ${ }^{10}$ Higher OM content, ${ }^{11,12}$ soil $\mathrm{pH}$ between 5.4 and 8.0, ${ }^{11}$ and soil moisture close to field capacity are expected to maximize $S$ oxidation rates, ${ }^{13,14}$ as well as temperatures between 30 and 40 ${ }^{\circ} \mathrm{C} .{ }^{15}$

The oxidation of ES occurs under aerobic conditions and is an acid-producing process. Many microorganisms can oxidize ES $\left(S^{0}\right)$ to $\mathrm{SO}_{4}{ }^{2-}$, but the most efficient are the chemoautotrophic bacteria Acidithiobacillus thiooxidans and Acidithiobacillus ferrooxidans. ${ }^{16-18}$ However, these organisms are almost absent in most agricultural soils ${ }^{7,19,20}$ due to soil chemical properties and the absence of an energy source for these microorganisms in aerated soil. Heterotrophic microorganisms, both bacteria and fungi, can also be important ES oxidizers in agricultural soils. $^{20-22}$

Elemental $\mathrm{S}$ is produced predominantly by recovery from the oil and gas industry, ${ }^{23}$ and the low price of this concentrated $S$ form has recently stimulated its wider use. Traditionally, ES is a primary source for sulfuric acid production that is then used to manufacture phosphates as well as other soluble fertilizers. When ES is used directly as a S source in fertilizer, it is often cogranulated with rock phosphate or granular fertilizers including urea, single and triple superphosphate, mono- and diammonium phosphate, and potassium chloride. ${ }^{24}$ In addition, pastilles containing ES and bentonite (90\% ES and 10\% bentonite) have been made after a $S$ melting process. $^{25}$

Received: November 8, 2016

Revised: January 26, 2017

Accepted: January 27, 2017

Published: January 27, 2017 
Zinc oxide is a cheap source of zinc, but it is not readily available to plants when banded or added in granular form. ${ }^{26,27}$ Furthermore, the distribution of pure micronutrient granular fertilizers even dry blended with macronutrient fertilizers results in poor $\mathrm{Zn}$ distribution, which limits plant uptake. We hypothesized that co-granulating $\mathrm{Zn}$ with ES fertilizers may be beneficial to achieve adequate $\mathrm{Zn}$ distribution and, importantly, the acidity generated during the ES oxidation could enhance $\mathrm{ZnO}$ dissolution according to the following reaction, that is, the oxidation of $1 \mathrm{~mol}$ of ES supplies enough protons to dissolve $1 \mathrm{~mol}$ of $\mathrm{ZnO}$ :

$$
\mathrm{S}^{0}+\mathrm{ZnO}+{ }^{3} / 2 \mathrm{O}_{2} \rightarrow \mathrm{ZnSO}_{4}
$$

A fertilizer made of $\mathrm{ES}$ and $\mathrm{ZnO}$ would have the advantage of higher nutrient concentrations and lower cost compared to traditional soluble sources of $\mathrm{S}$ or $\mathrm{Zn}$.

The objectives of the present work were to produce cogranulated ES-Zn fertilizers and evaluate ES oxidation and $S$ and $\mathrm{Zn}$ availability in soils with contrasting $\mathrm{pH}$. We also assessed the oxidation of ES in fertilizers enriched with sugar and known S-oxidizing microorganisms (A. thiooxidans or Aspergillus niger).

\section{MATERIALS AND METHODS}

Fertilizer Manufacturing. Elemental sulfur-zinc granular fertilizer $\left(\mathrm{ES}-\mathrm{Zn}_{\text {control }}\right)$ with the composition $\mathrm{ES}(80 \%), \mathrm{ZnO}(5 \%)$, sodium bentonite (Na-bentonite; $7.5 \%)$, sucrose (5\%), and inulin (2.5\%) was produced using a laboratory granulator with an atomized water spray addition. To assess if sugar had an effect on ES oxidation, an additional control fertilizer with no sugar $\left(\mathrm{ES}-\mathrm{Zn}_{\text {nosugar }}\right)$ was produced with the following composition: $\mathrm{ES}$ (86.5\%); $\mathrm{ZnO}(5.5 \%)$; Na-bentonite $(8.0 \%)$. For the bacteria-inoculated fertilizer, sucrose was omitted and replaced by inulin to avoid inhibition of bacterial growth. ${ }^{28}$ Inulin was also used to increase granule hardness.

Microorganisms. A. thiooxidans (ATCC19377; NCIMB 8343) and $A$. niger (ATCC 8740) cultures were grown on $9 \mathrm{~K}$ and potato dextrose agar (PDA) media, respectively, both for 10 days prior to culture preparation. Then, the fertilizer was inoculated with microorganisms via a solution with $8.2 \times 10^{8}$ cells $\mathrm{mL}^{-1}$ of bacteria or $1.9 \times$ $10^{7}$ conidia $\mathrm{mL}^{-1}$ of fungus sprayed with dispersive Triton solution $(0.1 \%)$ during the granulation process. Thus, ES-Zn fertilizers inoculated with $A$. thiooxidans $\left(\mathrm{ES}-\mathrm{Zn}_{\text {thiooxidans }}\right.$ ) and $A$. niger (ES$\mathrm{Zn}_{\text {niger }}$ ) were produced. Prior to application, the number of bacterial cells and conidia in suspension was counted using a hemocytometer (depth, $0.1 \mathrm{~mm}$; area, $0.0025 \mathrm{~mm}^{2}$ ). The bacterial cells were stained using Crystal Violet staining reagent. ${ }^{29}$

The particle size for all dry compounds ranged between 20 and 75 $\mu \mathrm{m}$. The granules were sized between 2.5 and $3.0 \mathrm{~mm}$. The fertilizers were dried at $35^{\circ} \mathrm{C}$ for $48 \mathrm{~h}$ and stored at room temperature (around $22{ }^{\circ} \mathrm{C}$ ). Whole granule and hand-cut cross sections were imaged using a Leica Wild Optical Microscope M420 fitted with a Lumenera Infinity 4, 11 megapixel digital camera and Lumenera "Infinity Analyze" software. An FEI Quanta 450 FEG environmental scanning electron microscope (ESEM) was used to image cross sections and produce elemental maps of $\mathrm{S}$ and $\mathrm{Zn}$ to investigate nutrient distribution.

Petri Dish Experiments. Two agricultural soils with contrasting $\mathrm{pH}$ values were used because soil $\mathrm{pH}$ is an important factor affecting ES oxidation and $\mathrm{Zn}$ reactions in soil (Table 1). The soil orders are Alfisol (Monarto, South Australia) and Tenosol (Eneabba, Western Australia), as classified according to the Australian Soil Classification. ${ }^{30}$ The soils were collected from the top layer $(0-10 \mathrm{~cm})$, air-dried, and sieved to $<2 \mathrm{~mm}$ prior to use. A Petri dish experiment was carried out to evaluate the release of $S$ and $\mathrm{Zn}$ from the fertilizers through chemical analyses and visualization of $\mathrm{Zn}$ diffusion (see below). The equivalent of $20 \mathrm{~g}$ of air-dried soil was placed in a Petri dish $(55 \mathrm{~mm}$ diameter $\times 10 \mathrm{~mm}$ height), ensuring a flat soil surface.
Table 1. Selected Soil Characteristics

\begin{tabular}{lll}
\multicolumn{1}{c}{ soil characteristic } & Eneabba & Monarto \\
$\mathrm{pH}\left(\mathrm{CaCl}_{2}\right)$ & 5.5 & 7.0 \\
$\mathrm{pH}\left(\mathrm{H}_{2} \mathrm{O}\right)$ & 6.5 & 7.8 \\
organic carbon $\left(\mathrm{g} \mathrm{kg}^{-1}\right)$ & 15 & 10 \\
total $\mathrm{S}^{a}\left(\mathrm{mg} \mathrm{kg}^{-1}\right)$ & 84.5 & 99 \\
total $\mathrm{Zn}^{a}\left(\mathrm{mg} \mathrm{kg}^{-1}\right)$ & 3.5 & 29.5 \\
total $\mathrm{P}^{a}\left(\mathrm{mg} \mathrm{kg}^{-1}\right)$ & 49.5 & 127 \\
clay $\left(\mathrm{g} \mathrm{kg}^{-1}\right)$ & 27 & 80 \\
silt $\left(\mathrm{g} \mathrm{kg}^{-1}\right)$ & 12 & 70 \\
fine sand $\left(\mathrm{g} \mathrm{kg}^{-1}\right)$ & 180 & 680 \\
coarse sand $\left(\mathrm{g} \mathrm{kg}^{-1}\right)$ & 770 & 160
\end{tabular}

${ }^{a_{T}}$ Total S, Zn, and P measured after aqua regia digestion.

The four granulated ES-Zn fertilizers, ES- $\mathrm{Zn}_{\text {control }}$ ES $-\mathrm{Zn}_{\text {nosugar }}$ $\mathrm{ES}-\mathrm{Zn}_{\text {niger }}$, and $\mathrm{ES}-\mathrm{Zn}_{\text {thiooxidans, }}$, and a commercial ES pastille $(90 \% \mathrm{~S}$ and $10 \%$ bentonite) were evaluated. The treatments with pastille fertilizer was excluded from $\mathrm{Zn}$ diffusion visualization tests because they contained no Zn. A single granule or pastille of ca. $17 \mathrm{mg}$ (about $14 \mathrm{mg}$ of $\mathrm{S}$ and $0.7 \mathrm{mg}$ of $\mathrm{Zn}$ ) was applied in the center of the Petri

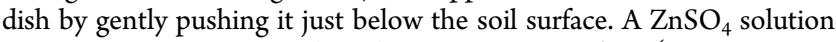
or $\mathrm{ZnO}$ suspension, providing the same amount of $\mathrm{Zn}(0.7 \mathrm{mg} \mathrm{Zn}$ per dish), was used as reference treatment for $\mathrm{Zn}$ diffusion. Both were applied by pipetting $20 \mu \mathrm{L}$ of a solution or suspension in a small hole made in the center of the Petri dish. Then, the soil was wetted to $80 \%$ field capacity by spraying. The Petri dishes were sealed with Parafilm to minimize water loss while maintaining aeration and incubated at 25 ${ }^{\circ} \mathrm{C}$ in the dark. After 1, 12, and 29 days of incubation, $\mathrm{Zn}$ diffusion was assessed following the method described by Degryse et al. ${ }^{31}$ Briefly, a $\mathrm{CaCO}_{3}$-impregnated filter paper (Whatman Nno. 1, $55 \mathrm{~mm}$ diameter), which acts as a sink for $\mathrm{Zn}$, was placed on the soil surface. After $1-3 \mathrm{~h}$ of exposure ( $1 \mathrm{~h}$ for 1 day of incubation and $3 \mathrm{~h}$ for 12 and 29 days of incubation), the $\mathrm{Zn}$ captured on the paper was colored with dithizone reagent. The filter papers were left to air-dry and then scanned. Images were analyzed using GIMP (v. 2.6.11) software for image processing to quantify the pink area corresponding to the high $\mathrm{Zn}$ zone. The diffusion radius (DR) was calculated using the equation

$$
\mathrm{DR}=\sqrt{ } A / \pi
$$

where $A$ is the area of the high $\mathrm{Zn}$ zone.

The remaining samples were incubated for 30 or 60 days prior to chemical analysis. Concentric soil samples at $0-5 \mathrm{~mm}$ (inner section) and 5-9 $\mathrm{mm}$ (outer section) from the fertilizer application point were collected using a cork borer, then air-dried and homogenized before chemical analysis.

Chemical Analyses. The $\mathrm{pH}$ and extractable $\mathrm{S}$ and $\mathrm{Zn}$ concentrations were determined in $10 \mathrm{mmol} \mathrm{L}^{-1} \mathrm{CaCl}_{2}$ at a liquid/ solid ratio $(\mathrm{L} / \mathrm{S})$ of $5 \mathrm{~L} \mathrm{~kg}^{-1}$. About $0.7 \mathrm{~g}$ (inner section soil, including the granule) or $1.25 \mathrm{~g}$ (outer section) of air-dried soil was shaken with $\mathrm{CaCl}_{2}$ solution for $30 \mathrm{~min}^{32}$ Samples were centrifuged for $10 \mathrm{~min}$ at $4000 \mathrm{~g}$, and a subsample of the supernatant was filtered through a 0.45 $\mu \mathrm{m}$ filter. Sulfur and $\mathrm{Zn}$ concentrations in the filtered extracts were determined using inductively coupled plasma atomic emission spectroscopy (ICP-AES; PerkinElmer 7000 DV, US). The $\mathrm{pH}$ was determined on the remainder of the suspension after shaking.

Residual ES in the soil was extracted with chloroform. ${ }^{33}$ About $0.7 \mathrm{~g}$ of air-dried soil from the inner section, including the granule, was shaken with $4 \mathrm{~mL}$ of water, to promote soil dispersion, and $8 \mathrm{~mL}$ of chloroform for $2 \mathrm{~h}$. The suspension was centrifuged for $20 \mathrm{~min}$ at $4600 \mathrm{~g}$, and an aliquot of $40 \mu \mathrm{L}$ of chloroform extract (bottom) was pipetted, diluted with methanol, and stored at $-20{ }^{\circ} \mathrm{C}$. The determination of ES was performed by high-performance liquid chromatography (HPLC, Agilent, USA). A standard stock solution of ES $\left(500 \mathrm{mg} \mathrm{L}^{-1} \mathrm{~S}\right)$ was made by dissolving powdered ES in a mixture of chloroform and methanol at a ratio of 1:1. A standard curve from 0 to $30 \mathrm{mg} \mathrm{L}^{-1} \mathrm{~S}$ was obtained by diluting the stock solution with methanol. 

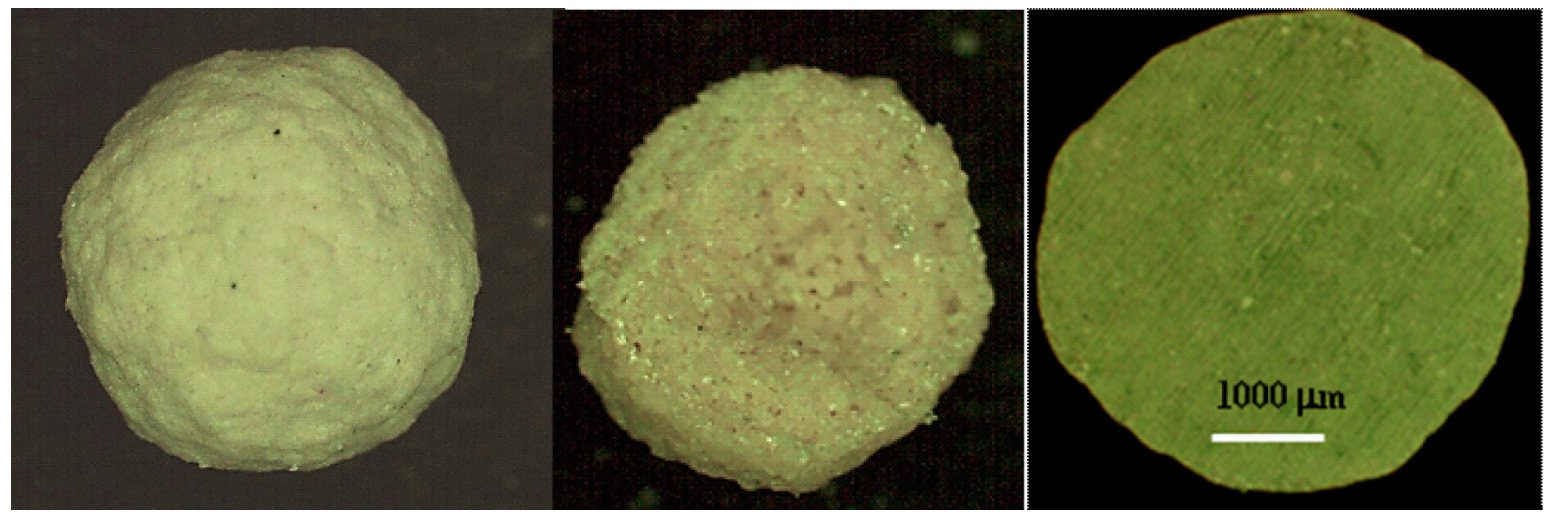

Figure 1. Optical microscope image of a whole (left) or sectioned (middle) ES-Zn granular fertilizer and a sulfur pastille (right).

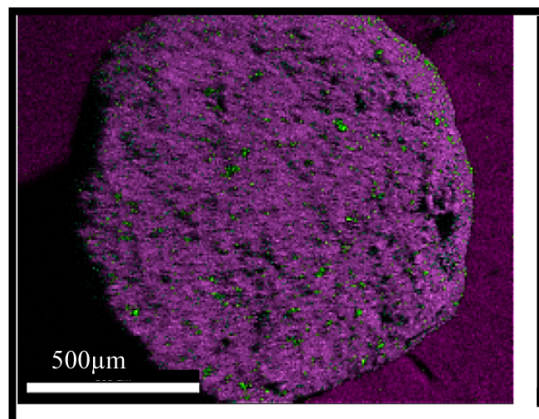

C, $\mathrm{O}$

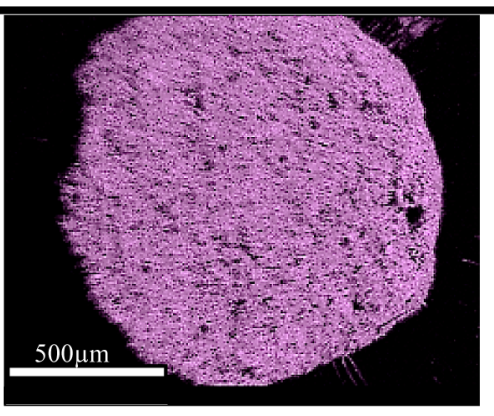

$\mathbf{S}$

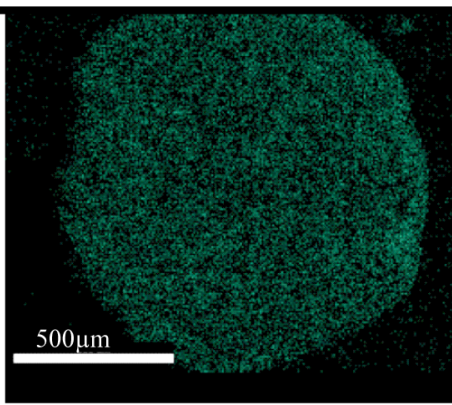

$\mathrm{Zn}$

$21 \%$ C K

$6 \% \mathrm{O} \mathrm{K}$

$63 \%$ S K

$1 \%$ ZnK

Figure 2. Elemental map images of granules obtained using scanning electron microscopy-energy dispersive X-ray analysis for the ES-Zn control sample in cross section showing the distribution of all elements (left), elemental S (middle), and Zn (right).

Sulfur oxidation was calculated using the amount of ES added and the amount recovered for each treatment by the following equation:

$S$ oxidation $\%=100-$

[(ES recovery from treatment $/ \mathrm{ES}$ recovery from fertilizer $) \times 100]$

For ES-Zn fertilizers, ES recovery by the chloroform method ranged from 88.2 to $95.4 \%$ for measurements after 60 and 30 days of incubation, respectively. For the pastille fertilizer, ES recovery by the chloroform method ranged from 86.3 to $91.2 \%$ for measurements after 60 and 30 days of incubation, respectively.

Microorganism Survival. The survival of inoculated microorganisms in the granules was evaluated in a culture medium from 1 to 97 days after their inoculation. For the fungus-inoculated treatment, the granules were placed in Petri dishes filled with 1.2\% PDA, and the characteristic A.nbs niger growth produced a positive visual result. To test the bacterial survival, we used the $9 \mathrm{~K}$ medium, $\mathrm{pH} 2.8$, with Thymol Blue indicator (0.05\%). Changes in color from yellow to red indicated bacterial growth when compared to the no-bacteria granules as control.

Data Analysis. The experiments were carried out using randomized block designs with three replications. Statistical analysis was carried out by one-way ANOVA followed by general linear model using the Statistical Analysis System. ${ }^{34}$ The differences among treatment means (fertilizers and soil) were analyzed using the LSMEANS procedure with the Tukey adjustment at $p \leq 0.05$. Pearson correlation analysis for $\mathrm{S}$ oxidation, $\mathrm{pH}$, and $\mathrm{CaCl}_{2}$-extractable $\mathrm{S}$ and $\mathrm{Zn}$ for the inner section was carried out by the correlation procedure using SAS.

\section{RESULTS}

Nutrient Distribution in the Granules. Elemental S-Zn fertilizer granules with a spherical shape were produced (Figures 1 and 2). The optical microscope image of the control sample shows that ES-Zn granules had higher porosity than the ES pastille, which is important for water penetration and microbial growth and activity when applied to soil. Scanning electron microscope images showed that both $S$ and $\mathrm{Zn}$ were very well distributed throughout the granules and that the potential issue of segregation and agglomeration during production, especially for $\mathrm{Zn}$, did not occur prior to, or during, granulation (Figure 2).

Zinc Diffusion. Zinc diffusion assessed by the visualization test showed large differences among treatments (Figures 3 and 4). The diffusion of $\mathrm{Zn}$ after 1 day was highest when $\mathrm{Zn}$ was 

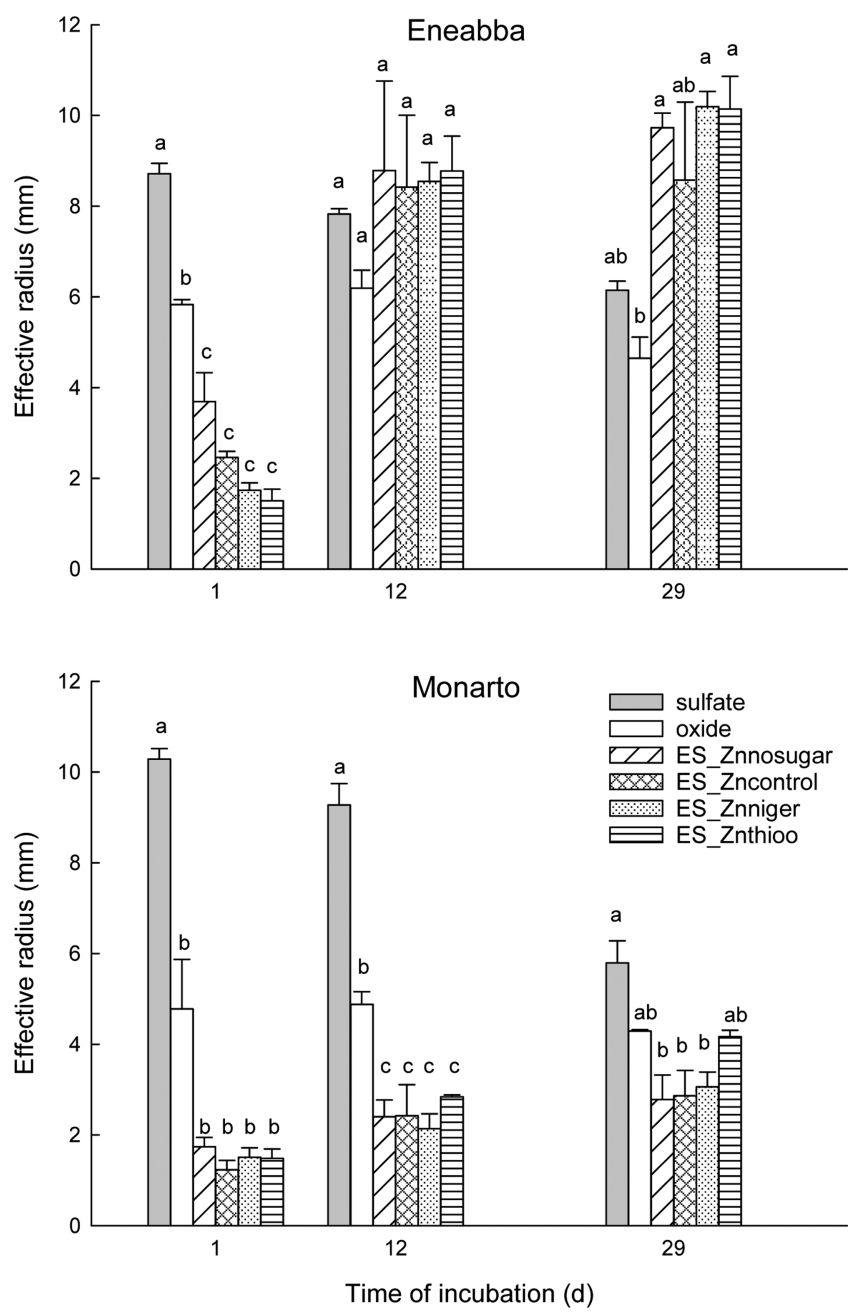

Figure 3. Radius of the high-Zn zone after 1, 12, or 29 days of incubation with $\mathrm{Zn}$ fertilizers placed in the center of the Petri dish in soil with low $\mathrm{pH}$ (Eneabba) and high $\mathrm{pH}$ (Monarto). Zinc was added to the soil at a rate of $0.7 \mathrm{mg}$ as a single granule of elemental sulfur (ES) $-\mathrm{Zn}$ fertilizer or a concentrated solution and suspension of $\mathrm{ZnSO}_{4}$ and $\mathrm{ZnO}$, respectively. Different letters for each time of incubation indicate significant differences between treatments (Tukey test, $p \leq 0.05$ ). The least significant difference (LSD) of effective radius to compare ES fertilizers over time of incubation is 1.45 and 0.60 for Eneabba and Monarto, respectively. Vertical bars over each mean are standard errors of three replicates. See Materials and Methods for full description of the fertilizers.

added as $\mathrm{ZnSO}_{4}$ in both soils. However, the high $\mathrm{Zn}$ zones were similar after 12 days for all fertilized treatments in the low$\mathrm{pH}$ soil (Eneabba). The ES-Zn fertilizers and $\mathrm{ZnO}$ had much higher diffusion after 12 days in the low-pH soil than in the high-pH soil (Monarto). In the high-pH soil, there was an increase in the high- $\mathrm{Zn}$ zone for ES- $\mathrm{Zn}$ fertilizers compared with a decrease for $\mathrm{ZnSO}_{4}$ between 1 and 29 days (Figures 3 and 4).

Soil pH. Acidification was observed after 30 days of incubation in both soil sections when ES-Zn fertilizers were applied to Eneabba soil (low-pH soil), and the $\mathrm{pH}$ further decreased between 30 and 60 days (Table 2). In the Monarto soil, there was little change in $\mathrm{pH}$. When ES-Zn fertilizer was inoculated with $A$. thiooxidans, there was a small but significant decrease in $\mathrm{pH}$ compared to the $\mathrm{ZnO}$ control in both soil sections at 60 days of incubation (Table 2). $\mathrm{ZnSO}_{4}$ addition
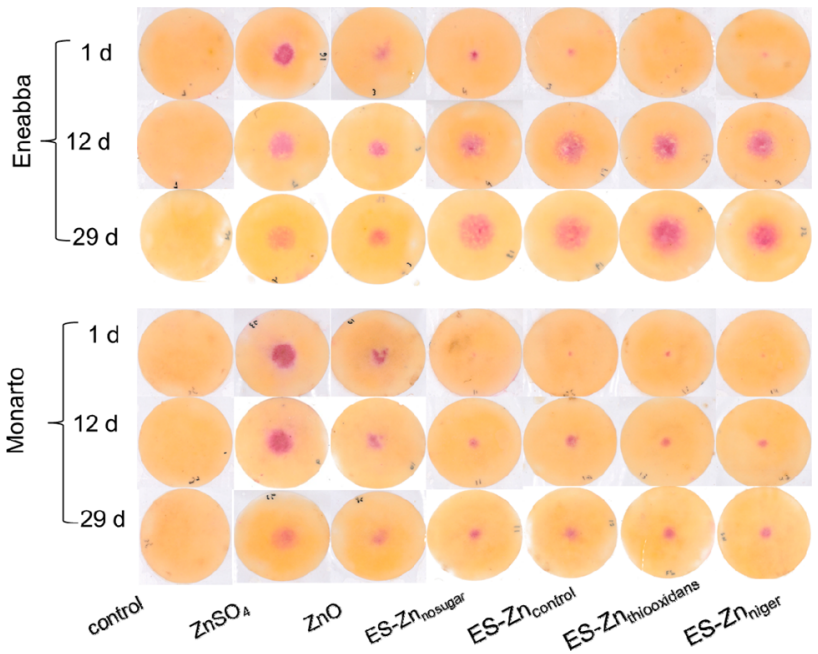

Figure 4. Visualization of $\mathrm{Zn}$ diffusion at 1, 12, and 29 days after addition of sulfur-zinc fertilizers in a sandy soil with a low $\mathrm{pH}$ (Eneabba) or a soil with high $\mathrm{pH}$ (Monarto). Zinc was added to the soil at a rate of $0.7 \mathrm{mg}$ of $\mathrm{Zn}$ as a single granule of elemental sulfur (ES) $-\mathrm{Zn}$ fertilizer or a concentrated solution or suspension of $\mathrm{ZnSO}_{4}$ or $\mathrm{ZnO}$. See Materials and Methods for full descriptions of the fertilizers.

decreased the $\mathrm{pH}$ slightly compared to the control (at 60 days for Eneabba and both sampling times for Monarto), and $\mathrm{ZnO}$ increased the $\mathrm{pH}$ in the Eneabba soil (Table 2).

Extractable $\mathbf{S}$ and $\mathbf{Z n}$. Application of ES-Zn fertilizers increased $\mathrm{S}$ and $\mathrm{Zn}$ extractable in the $\mathrm{CaCl}_{2}$ extract in the inner section $(0-5 \mathrm{~mm})$ as well in the midsection $(5-9 \mathrm{~mm}$ far from application point) in both soils (Tables 3 and 4). Although ES-Zn fertilizers did not induce significant changes in the $\mathrm{pH}$ of the Monarto soil (except ES- $\mathrm{Zn}_{\text {thiooxidans }}$ at 60 days), $\mathrm{Zn}$ and $S$ concentrations were increased in the inner soil section with their application.

Extractable $S$ remained high in the midsection far from the application point of S-containing fertilizers in the Eneabba soil (Table 3). As expected, $\mathrm{Zn}$ concentrations were higher in the Eneabba soil (with low $\mathrm{pH}$ ) than in the Monarto soil, which has a slightly alkaline $\mathrm{pH}$ (Table 4). Moreover, as shown in the $\mathrm{Zn}$ visualization test (Figures 3 and 4), this higher $\mathrm{Zn}$ concentration resulted in a wider $\mathrm{Zn}$ diffusion zone in the Eneabba soil compared with the Monarto soil.

Zinc diffusion was greater in the Monarto soil for the $\mathrm{ZnSO}_{4}$ treatment than for the other treatments, as evident from the higher $\mathrm{Zn}$ concentrations in the midsection (Table 4) and as was also indicated by the $\mathrm{Zn}$ visualization results (Figures 3 and 4). There was little difference between the ES-Zn fertilizers in the Monarto soil, except for the ES-Zn inoculated with A. thiooxidans, which showed higher $\mathrm{Zn}$ and $\mathrm{S}$ concentrations than the other treatments (Tables 3 and 4).

In the Eneabba soil, $S$ concentrations were generally lower for the ES pastille than for the ES-Zn fertilizers. There was little difference in $S$ or $\mathrm{Zn}$ concentrations between the ES-Zn fertilizers. The presence of sugar induced high $\mathrm{Zn}$ concentration in the inner soil section at 30 days of incubation, but this effect was not consistent over time (Table 4).

Residual ES and Oxidation Rate. Elemental $S$ oxidation was higher in the Eneabba soil than in the Monarto soil ( $p \leq$ 0.05 ), and it was significantly increased in the presence of A. thiooxidans at 30 days of incubation in both soils (Table 5). At this time, 20.9 and $12.0 \%$ of applied ES were oxidized, which 
Table 2. Soil $\mathrm{pH}$ in a $10 \mathrm{mmol} \mathrm{CaCl}_{2} \mathrm{~L}^{-1}$ Extract for Soil in $<5 \mathrm{~mm}$ (Inner Section) or 5-9 mm (Outer Section) Concentric Sections from the Fertilizer Application Point at 30 and 60 Days of Incubation ${ }^{a}$

\begin{tabular}{|c|c|c|c|c|}
\hline \multirow[b]{3}{*}{ fertilizer } & \multicolumn{4}{|c|}{$\mathrm{pH}$} \\
\hline & \multicolumn{2}{|c|}{30 days of incubation } & \multicolumn{2}{|c|}{60 days od incubation } \\
\hline & $\begin{array}{l}\text { inner } \\
\text { section }\end{array}$ & $\begin{array}{c}\text { outer } \\
\text { section }\end{array}$ & $\begin{array}{c}\text { inner } \\
\text { section }\end{array}$ & $\begin{array}{c}\text { outer } \\
\text { section }\end{array}$ \\
\hline \multicolumn{5}{|c|}{ Eneabba Soil } \\
\hline control & $5.30 \mathrm{cb}$ & $5.30 \mathrm{abc}$ & $5.55 b$ & $5.53 \mathrm{a}$ \\
\hline $\mathrm{ZnSO}_{4}$ & $5.37 \mathrm{~b}$ & $5.41 \mathrm{ab}$ & $5.31 \mathrm{c}$ & $5.18 b$ \\
\hline $\mathrm{ZnO}$ & $6.33 a$ & $5.46 a$ & $6.39 a$ & $5.50 \mathrm{a}$ \\
\hline $\mathrm{ES}-\mathrm{Zn}_{\text {nosugar }}$ & $5.05 \mathrm{~d}$ & $5.14 \mathrm{bcd}$ & $4.89 \mathrm{~d}$ & $4.97 \mathrm{c}$ \\
\hline $\mathrm{ES}-\mathrm{Zn}_{\text {control }}$ & $5.08 \mathrm{~cd}$ & $5.02 \mathrm{~d}$ & $4.83 \mathrm{de}$ & $4.94 c$ \\
\hline $\mathrm{ES}-\mathrm{Zn}_{\text {niger }}$ & $4.95 \mathrm{~d}$ & $5.03 \mathrm{~cd}$ & $4.80 \mathrm{de}$ & $4.91 c$ \\
\hline $\mathrm{ES}-\mathrm{Zn}_{\text {thiooxidans }}$ & $4.95 \mathrm{~d}$ & $4.97 \mathrm{~d}$ & $4.69 \mathrm{e}$ & $4.92 \mathrm{c}$ \\
\hline ES pastille & $5.12 \mathrm{~cd}$ & $5.08 \mathrm{~cd}$ & $4.80 \mathrm{de}$ & $4.92 \mathrm{c}$ \\
\hline av fertilizers ${ }^{b}$ & $5.26^{*}$ & $5.16 \#$ & 5.10 & 5.05 \\
\hline $\mathrm{LSD}^{c}$ & 0.25 & 0.27 & 0.13 & 0.11 \\
\hline $\mathrm{CV}^{d}(\%)$ & 1.65 & 1.52 & 0.92 & 0.72 \\
\hline \multicolumn{5}{|c|}{ Monarto Soil } \\
\hline control & $7.09 a$ & $7.08 b$ & $7.05 a$ & $7.15 a$ \\
\hline $\mathrm{ZnSO}_{4}$ & $6.85 b$ & $7.04 b$ & $6.86 \mathrm{~b}$ & $7.10 \mathrm{a}$ \\
\hline $\mathrm{ZnO}$ & $7.11 \mathrm{a}$ & $7.10 \mathrm{ab}$ & $7.11 \mathrm{a}$ & $7.10 \mathrm{a}$ \\
\hline $\mathrm{ES}--\mathrm{Zn}_{\text {nosugar }}$ & $7.14 \mathrm{a}$ & $7.10 \mathrm{ab}$ & $7.13 a$ & $7.12 \mathrm{a}$ \\
\hline $\mathrm{ES}-\mathrm{Zn}_{\text {control }}$ & $7.12 \mathrm{a}$ & 7.11ab & $7.09 \mathrm{a}$ & $7.12 \mathrm{a}$ \\
\hline $\mathrm{ES}-\mathrm{Zn}_{\text {niger }}$ & $7.14 \mathrm{a}$ & $7.09 \mathrm{ab}$ & $7.14 \mathrm{a}$ & $7.14 \mathrm{a}$ \\
\hline $\mathrm{ES}-\mathrm{Zn}_{\text {thiooxidans }}$ & $7.08 \mathrm{a}$ & $7.12 \mathrm{a}$ & $6.79 b$ & $7.00 \mathrm{~b}$ \\
\hline ES pastille & $7.14 \mathrm{a}$ & $7.13 \mathrm{a}$ & $7.13 a$ & $7.13 \mathrm{a}$ \\
\hline av fertilizers ${ }^{b}$ & $7.10 *$ & 7.10 & 7.04 & 7.10 \\
\hline LSD & 0.10 & 0.09 & 0.16 & 0.07 \\
\hline CV (\%) & 0.29 & 0.18 & 0.83 & 0.36 \\
\hline
\end{tabular}

${ }^{a}$ Different letters within a column indicate significant $(p \leq 0.05)$ differences by Tukey test for each soil. ${ }^{b *}$ and \# indicate significant $(p$ $\leq 0.05$ and $p \leq 0.10$, respectively) differences by $F$ test between time of incubation for inner-section and outer-section for each soil. ${ }^{c}$ Least significant difference $(p<0.05) .{ }^{d}$ Coefficient of variation for ANOVA.

corresponded to $\mathrm{S}$ oxidation rates of 95.6 and $54.8 \mu \mathrm{g} \mathrm{day}^{-1} \mathrm{~S}$ in the Eneabba and Monarto soils, respectively (Table 5). Elemental $S$ oxidation increased over time in both soils; however, at 60 days of incubation it was lowest for the ES pastille fertilizer, with 10.1 and $6.9 \%$ oxidized in the Eneabba and Monarto soil, respectively. At this time in Monarto soil, the $\mathrm{ES}-\mathrm{Zn}_{\text {thiooxidans }}$ treatment had a higher ES oxidation (17.6\% of applied ES) and oxidation rate $\left(39.9 \mu \mathrm{g} \mathrm{day}^{-1} \mathrm{~S}\right)$ than the pastille, but there was no significant difference from other treatments. Adding sugar or A. niger in these ES-Zn fertilizers had no influence on $S$ oxidation.

Given the relatively low percentage of ES oxidized, ES oxidation was calculated from the difference between two similar values (ES added and ES remaining), which inherently carries a large uncertainty. If there is no immobilization of sulfate-S, ES oxidation can also be calculated from the extractable $\mathrm{SO}_{4}-\mathrm{S}$ concentrations. The added $\mathrm{S}$ in the $\mathrm{ZnSO}_{4}$ treatment was fully recovered as $\mathrm{CaCl}_{2}$-extractable $\mathrm{S}$, indicating that there was little immobilization of $\mathrm{S}$ in these soils over this time frame. Assuming that there was no extra immobilization in the other treatments and that the soil $>9 \mathrm{~mm}$ of the application point had the same $\mathrm{CaCl}_{2}$-extractable $\mathrm{S}$ concentration as the remainder of the soil (because sulfate diffuses quickly in soil), it was estimated that up to $4 \%$ of added ES was oxidized. These
Table 3. Sulfur Extractable in a $10 \mathrm{mmol} \mathrm{L}^{-1} \mathrm{CaCl}_{2}$ Extract for Soil Taken from $<5 \mathrm{~mm}$ (Inner Section) or 5-9 mm (Outer Section) Concentric Sections from the Fertilizer Application Point at 30 and 60 Days of Incubation ${ }^{a}$

\begin{tabular}{|c|c|c|c|c|}
\hline \multirow[b]{3}{*}{ fertilizer } & \multicolumn{4}{|c|}{$\mathrm{CaCl}_{2}$-extractable $\mathrm{S}\left(\mathrm{mg} \mathrm{kg}^{-1}\right)$} \\
\hline & \multicolumn{2}{|c|}{30 days of incubation } & \multicolumn{2}{|c|}{60 days of incubation } \\
\hline & $\begin{array}{c}\text { inner } \\
\text { section }\end{array}$ & $\begin{array}{c}\text { outer } \\
\text { section }\end{array}$ & $\begin{array}{c}\text { inner } \\
\text { section }\end{array}$ & $\begin{array}{c}\text { outer } \\
\text { section }\end{array}$ \\
\hline \multicolumn{5}{|c|}{ Eneabba Soil } \\
\hline control & $10.7 \mathrm{~b}$ & $7.8 \mathrm{c}$ & $9.9 \mathrm{c}$ & $6.9 \mathrm{~b}$ \\
\hline $\mathrm{ZnSO}_{4}$ & $24.0 \mathrm{ab}$ & $23.1 \mathrm{ab}$ & $27.4 \mathrm{a}$ & $27.2 \mathrm{a}$ \\
\hline $\mathrm{ZnO}$ & $11.4 \mathrm{~b}$ & $7.1 \mathrm{c}$ & $11.9 \mathrm{bc}$ & 9.9ab \\
\hline $\mathrm{ES}-\mathrm{Zn}_{\text {nosugar }}$ & $30.6 a$ & $29.0 \mathrm{a}$ & $30.9 \mathrm{a}$ & $29.3 a$ \\
\hline $\mathrm{ES}-\mathrm{Zn}_{\text {control }}$ & $36.2 \mathrm{a}$ & $24.7 \mathrm{ab}$ & $28.3 a$ & $26.7 \mathrm{ab}$ \\
\hline $\mathrm{ES}-\mathrm{Zn}_{\text {niger }}$ & $31.8 \mathrm{a}$ & $28.1 \mathrm{a}$ & $27.6 \mathrm{a}$ & $27.2 \mathrm{a}$ \\
\hline $\mathrm{ES}-\mathrm{Zn}_{\text {thiooxidans }}$ & $34.6 \mathrm{a}$ & $27.2 \mathrm{a}$ & $35.0 \mathrm{a}$ & $29.3 a$ \\
\hline ES pastille & $29.4 a$ & $13.8 \mathrm{bc}$ & $16.0 \mathrm{~b}$ & $15.1 \mathrm{ab}$ \\
\hline av fertilizers ${ }^{b}$ & $28.3 \mathrm{~ns}$ & $21.9 \mathrm{~ns}$ & 25.3 & 23.5 \\
\hline $\operatorname{LSD}^{c}$ & 16.6 & 12.7 & 19.3 & 20 \\
\hline $\mathrm{CV}^{d}(\%)$ & 22 & 18 & 29 & 31 \\
\hline \multicolumn{5}{|c|}{ Monarto Soil } \\
\hline control & $6.6 \mathrm{c}$ & $4.8 \mathrm{~b}$ & $5.0 \mathrm{~b}$ & $4.8 \mathrm{c}$ \\
\hline $\mathrm{ZnSO}_{4}$ & $23.7 \mathrm{a}$ & $26.9 \mathrm{a}$ & $26.1 \mathrm{a}$ & $25.3 \mathrm{a}$ \\
\hline $\mathrm{ZnO}$ & $5.8 \mathrm{c}$ & $4.3 b$ & $4.3 b$ & $4.5 c$ \\
\hline $\mathrm{ES}-\mathrm{Zn}_{\text {nosugar }}$ & $10.3 \mathrm{bc}$ & $5.1 \mathrm{~b}$ & $6.6 \mathrm{~b}$ & $5.0 \mathrm{c}$ \\
\hline $\mathrm{ES}-\mathrm{Zn}_{\text {control }}$ & $14.6 \mathrm{abc}$ & $6.7 \mathrm{~b}$ & $13.7 \mathrm{ab}$ & $7.5 \mathrm{c}$ \\
\hline $\mathrm{ES}-\mathrm{Zn}_{\text {niger }}$ & $13.5 \mathrm{abc}$ & $6.3 b$ & $9.7 \mathrm{~b}$ & $7.7 \mathrm{c}$ \\
\hline $\mathrm{ES}-\mathrm{Zn}_{\text {thiooxidans }}$ & $25.4 \mathrm{a}$ & $12.1 \mathrm{ab}$ & $19.7 \mathrm{ab}$ & $14.6 \mathrm{~b}$ \\
\hline ES pastille & $21.0 \mathrm{ab}$ & $9.5 b$ & $15.1 \mathrm{ab}$ & $6.5 \mathrm{c}$ \\
\hline av fertilizers ${ }^{b}$ & $16.3 \mathrm{~ns}$ & $10.1 \mathrm{~ns}$ & 13.6 & 10.1 \\
\hline $\mathrm{LSD}^{c}$ & 12.7 & 17.3 & 15.5 & 3.2 \\
\hline CV (\%) & 27 & 54 & 43 & 10 \\
\hline
\end{tabular}

${ }^{a}$ Different letters within a column indicate significant $(p \leq 0.05)$ differences by Tukey test. ${ }^{b}$ ns, nonsignificant $(p>0.05)$ differences by $F$ test between time of incubation for inner section and outer section for each soil. ${ }^{c}$ Least significant difference $(p<0.05)$. ${ }^{d}$ Coefficient of variation for ANOVA.

values are more realistic for whole ES pastilles enclosed by soil (which cannot disintegrate into small ES particles), which have been found to oxidize at rates around $0.05 \%$ per day, corresponding to around $10 \mu \mathrm{g} \mathrm{S}$ day $^{-1}$. 35,36

The oxidation of ES showed a significant negative correlation with soil $\mathrm{pH}$ and a positive correlation with extractable $\mathrm{S}$ of inner section soil (Table 6). Moreover, there was a negative and significant correlation between soil $\mathrm{pH}$ and extractable $\mathrm{S}$ or $\mathrm{Zn}$. Extractable $\mathrm{S}$ and $\mathrm{Zn}$ had a positive and significant correlation (Table 6). There was no significant correlation between ES oxidation and extractable $\mathrm{Zn}$ using all data, but it was positive and significant in Monarto soil (Table 6).

\section{DISCUSSION}

Sulfur oxidation and consequent $\mathrm{pH}$ reduction around the granules can be an important strategy to increase $\mathrm{Zn}$ efficiency for soil application. Our results showed a decrease in soil $\mathrm{pH}$ around the ES granule in the Eneabba soil with lower $\mathrm{pH}$ (5.5). In the Monarto soil, which has a higher $\mathrm{pH}$ buffering capacity, only the treatment with $A$. thiooxidans showed a significant change in $\mathrm{pH}$ as a result of ES addition. The increase in diffusion of $\mathrm{Zn}$ with $\mathrm{ES}-\mathrm{Zn}$ application after 12 days in the low-pH soil and at 29 days in the high-pH soil (see Figures 3 and 4), together with the increase in S and $\mathrm{Zn}$ extractable in 10 
Table 4. Zinc Extractable in $10 \mathrm{mmol} \mathrm{L}^{-1} \mathrm{CaCl}_{2}$ Extract for Soil Taken from $<5 \mathrm{~mm}$ (Inner Section) or 5-9 mm (Outer Section) Concentric Sections from the Fertilizer Application Point at 30 and 60 Days of Incubation ${ }^{a}$

\begin{tabular}{|c|c|c|c|c|}
\hline \multirow[b]{3}{*}{ fertilizer } & \multicolumn{4}{|c|}{$\mathrm{CaCl}_{2}$ extractable $\mathrm{Zn}\left(\mathrm{mg} \mathrm{kg}^{-1}\right)$} \\
\hline & \multicolumn{2}{|c|}{30 days of incubation } & \multicolumn{2}{|c|}{60 days of incubation } \\
\hline & $\begin{array}{l}\text { inner } \\
\text { section }\end{array}$ & $\begin{array}{c}\text { outer } \\
\text { section }\end{array}$ & $\begin{array}{l}\text { inner } \\
\text { section }\end{array}$ & $\begin{array}{l}\text { outer } \\
\text { section }\end{array}$ \\
\hline \multicolumn{5}{|c|}{ Eneabba Soil } \\
\hline control & $0.8 \mathrm{c}$ & $0.5 \mathrm{c}$ & $0.3 b$ & $0.25 b$ \\
\hline $\mathrm{ZnSO}_{4}$ & $53.2 b$ & $34.7 \mathrm{ab}$ & $30.3 a$ & $24.5 \mathrm{a}$ \\
\hline $\mathrm{ZnO}$ & $65.1 \mathrm{ab}$ & $22.4 \mathrm{~b}$ & $47.5 \mathrm{a}$ & $22.2 \mathrm{a}$ \\
\hline $\mathrm{ES}-\mathrm{Zn}_{\text {nosugar }}$ & $59.1 \mathrm{~b}$ & $41.6 a$ & $36.2 \mathrm{a}$ & $23.8 \mathrm{a}$ \\
\hline $\mathrm{ES}-\mathrm{Zn}_{\text {control }}$ & $99.5 \mathrm{a}$ & $41.9 \mathrm{a}$ & $25.2 \mathrm{a}$ & $21.9 a$ \\
\hline $\mathrm{ES}-\mathrm{Zn} \mathrm{n}_{\text {niger }}$ & $69.1 b$ & $53.0 \mathrm{a}$ & $31.4 \mathrm{a}$ & $25.7 \mathrm{a}$ \\
\hline $\mathrm{ES}-\mathrm{Zn}_{\text {thiooxidans }}$ & $93.8 \mathrm{ab}$ & $51.0 \mathrm{a}$ & $25.3 a$ & $21.7 \mathrm{a}$ \\
\hline ES pastille & $0.7 \mathrm{c}$ & $0.4 \mathrm{c}$ & $1.2 \mathrm{~b}$ & $0.5 \mathrm{~b}$ \\
\hline av fertilizers ${ }^{b}$ & $62.9^{*}$ & $35.0^{*}$ & 24.7 & 18.0 \\
\hline $\mathrm{LS}^{c}$ & 30 & 18.7 & 23.5 & 19.9 \\
\hline $\mathrm{CV}^{d}(\%)$ & 32 & 17 & 32 & 18 \\
\hline \multicolumn{5}{|c|}{ Monarto Soil } \\
\hline control & $0.1 \mathrm{c}$ & $0.1 b$ & $0.1 b$ & $0.1 \mathrm{~b}$ \\
\hline $\mathrm{ZnSO}_{4}$ & $9.0 \mathrm{a}$ & $1.7 \mathrm{a}$ & $6.8 \mathrm{ab}$ & $1.75 \mathrm{a}$ \\
\hline $\mathrm{ZnO}$ & $5.2 b$ & $0.1 b$ & $4.4 \mathrm{ab}$ & $0.65 b$ \\
\hline $\mathrm{ES}-\mathrm{Zn}_{\text {nosugar }}$ & $4.0 \mathrm{~b}$ & $0.1 b$ & $3.9 \mathrm{ab}$ & $0.1 \mathrm{~b}$ \\
\hline $\mathrm{ES}-\mathrm{Zn}_{\text {control }}$ & $4.9 \mathrm{~b}$ & $0.1 b$ & $6.1 \mathrm{ab}$ & $0.1 \mathrm{~b}$ \\
\hline $\mathrm{ES}-\mathrm{Zn}_{\text {niger }}$ & $4.7 \mathrm{~b}$ & $0.1 b$ & $4.8 \mathrm{ab}$ & $0.1 \mathrm{~b}$ \\
\hline $\mathrm{ES}-\mathrm{Zn}_{\text {thiooxidans }}$ & $10.6 a$ & $0.2 b$ & $20.2 \mathrm{a}$ & $1.85 \mathrm{a}$ \\
\hline ES pastille & $0.1 \mathrm{c}$ & $0.1 b$ & $0.3 b$ & $0.1 b$ \\
\hline av fertilizers & 5.5 & 0.3 & 5.8 & 0.55 \\
\hline LSD & 3.3 & 0.7 & 18 & 1.0 \\
\hline CV (\%) & 28 & 67 & 60 & 61 \\
\hline
\end{tabular}

${ }^{a}$ Different letters within a column indicate significant $(p \leq 0.05)$ differences by Tukey test for each soil. ${ }^{b *}$ indicates significant $(p \leq$ 0.05 ) differences by $F$ test between time of incubation for inner section and outer section for each soil. ${ }^{c}$ Least significant difference $(p<0.05)$. ${ }^{d}$ Coefficient of variation for ANOVA.

mmol L ${ }^{-1} \mathrm{CaCl}_{2}$, suggests increases in $\mathrm{Zn}$ availability in both soils.

Although ES is used as a S source in fertilizers, few fertilizer products have combined ES with cationic micronutrients. The oxidation of ES induces acidification, which may increase the availability of cationic micronutrients in soil. The $\mathrm{CaCl}_{2-}$ extractable $\mathrm{Zn}$ from co-granulated $\mathrm{ES}$ with $\mathrm{ZnO}$ was similar to or higher than that for the common $\mathrm{Zn}$ sources in fertilizers, $\mathrm{ZnSO}_{4}$, or $\mathrm{ZnO}$. Additionally, these fertilizers provide a progressive release of plant-available $S$. Fertilizers formulated using $\mathrm{ES}$ and $\mathrm{ZnO}$ have a high nutrient concentration and therefore should be cheaper to transport than other $\mathrm{S}$ or $\mathrm{Zn}$ fertilizers. Moreover, using raw materials such as ES and micronutrients in oxide forms will have less of an environmental impact for fertilizer production due to significantly less processing being involved in their manufacture. Thus, ES-Zn fertilizers may be a competitive source of both $\mathrm{S}$ and $\mathrm{Zn}$ for fertilizer application.

Considering the impractical application of ES to soil as a fine powder, granules or pastille forms are a more appropriate way for soil fertilization. However, incorporation of ES in granules or pastilles reduces the exposed surface area of ES and reduces $S$ oxidation. ${ }^{36}$ The effectiveness of ES as a granular or pastille fertilizer depends on oxidation rate, and residual effects should
Table 5. Sulfur Oxidized $\left(S_{O x i}\right)$ and Oxidation Rate (OR) for Inner Section Soil after Incubation Time of 30 and 60 Days with Elemental Sulfur Fertilizers ${ }^{a}$

\begin{tabular}{|c|c|c|c|c|}
\hline \multirow[b]{2}{*}{ fertilizer } & \multicolumn{2}{|c|}{30 days of incubation } & \multicolumn{2}{|c|}{60 days of incubation } \\
\hline & $\mathrm{S}_{\text {Oxi }}(\%)$ & $\begin{array}{c}\mathrm{OR} \\
\left(\mu \mathrm{g} \mathrm{S}^{-1} \text { day }^{-1}\right)\end{array}$ & $\mathrm{S}_{\mathrm{Oxi}}(\%)$ & $\begin{array}{c}\mathrm{OR} \\
\left.\left(\mu \mathrm{g} \mathrm{S}^{-1}\right) y^{-1}\right)\end{array}$ \\
\hline \multicolumn{5}{|c|}{ Eneabba Soil } \\
\hline $\mathrm{ES}-\mathrm{Zn}_{\text {nosugar }}$ & $8.5 b$ & $41.0 \mathrm{~b}$ & $19.8 \mathrm{ab}$ & $45.3 \mathrm{ab}$ \\
\hline $\mathrm{ES}-\mathrm{Zn}_{\text {control }}$ & $7.5 b$ & $31.7 \mathrm{~b}$ & $18.2 \mathrm{ab}$ & $41.8 \mathrm{ab}$ \\
\hline $\mathrm{ES}-\mathrm{Zn}_{\text {niger }}$ & $9.6 \mathrm{~b}$ & $45.0 \mathrm{ab}$ & $18.6 \mathrm{ab}$ & $44.5 \mathrm{ab}$ \\
\hline $\mathrm{ES}-\mathrm{Zn}_{\text {thiooxidans }}$ & $20.9 a$ & $95.6 \mathrm{a}$ & $22.6 a$ & $52.3 \mathrm{a}$ \\
\hline ES pastille & $4.6 \mathrm{~b}$ & $23.0 \mathrm{~b}$ & $10.1 b$ & $22.0 \mathrm{~b}$ \\
\hline $\mathrm{av}^{b}$ & $10.2^{*}$ & $47.3^{*}$ & $17^{*}$ & $41.2^{*}$ \\
\hline $\operatorname{LSD}^{c}$ & 10.6 & 52 & 10.6 & 25 \\
\hline $\mathrm{CV}^{d}(\%)$ & 34 & 36 & 21 & 22 \\
\hline \multicolumn{5}{|c|}{ Monarto Soil } \\
\hline $\mathrm{ES}-\mathrm{Zn}_{\text {nosugar }}$ & $6.8 \mathrm{ab}$ & $37.2 \mathrm{ab}$ & $9.2 \mathrm{ab}$ & $21.2 \mathrm{ab}$ \\
\hline $\mathrm{ES}-\mathrm{Zn}_{\text {control }}$ & $3.8 \mathrm{~b}$ & $16.4 b$ & $10.0 \mathrm{ab}$ & $23.9 \mathrm{ab}$ \\
\hline $\mathrm{ES}-\mathrm{Zn}_{\text {niger }}$ & $9.1 \mathrm{ab}$ & $42.2 \mathrm{ab}$ & $8.4 \mathrm{ab}$ & $19.1 \mathrm{ab}$ \\
\hline $\mathrm{ES}-\mathrm{Zn}_{\text {thiooxidans }}$ & $12.0 \mathrm{a}$ & $54.8 \mathrm{ab}$ & $17.6 \mathrm{a}$ & $39.9 \mathrm{a}$ \\
\hline ES pastille & $3.7 \mathrm{~b}$ & $17.5 b$ & $6.9 \mathrm{~b}$ & $15.9 \mathrm{~b}$ \\
\hline $\mathrm{av}^{\mathrm{b}}$ & 8.3 & $33.6 \#$ & 10.4 & 24 \\
\hline LSD & 8.0 & 36 & 10.3 & 23.7 \\
\hline CV (\%) & 40 & 39 & 40 & 42 \\
\hline
\end{tabular}

${ }^{a}$ Different letters within a column indicate significant $(p \leq 0.05)$ differences by Tukey test. ${ }^{b}$ and \# indicate significant $(p \leq 0.05$ and $p$ $\leq 0.10$, respectively) differences by $\mathrm{F}$ test between time of incubation for inner-section and outer-section soil. ${ }^{c}$ Least significant difference $(p$ $=0.05) .{ }^{d}$ Coefficient of variation for ANOVA.

Table 6. Pearson Correlation Coefficients for $S$ Oxidation, $\mathrm{pH}$, and $\mathrm{CaCl}_{2}$-Extractable $\mathrm{S}$ and $\mathrm{Zn}$ for Inner Sections of Two Australian Soils with ES-Zn Fertilizers Applied ${ }^{a}$

\begin{tabular}{|c|c|c|c|c|}
\hline variable & $S$ oxidation & $\mathrm{pH}$ & extractable S & extractable $\mathrm{Zn}$ \\
\hline \multicolumn{5}{|c|}{ General } \\
\hline$S$ oxidation & & $-0.489 * *$ & $0.351^{* * *}$ & 0.197 \\
\hline $\mathrm{pH}$ & & & $-0.690 * *$ & $-0.569 * *$ \\
\hline extractable $S$ & & & & $0.605^{* *}$ \\
\hline \multicolumn{5}{|c|}{ Eneabba Soil } \\
\hline$S$ oxidation & & $-0.521 * *$ & -0.097 & -0.191 \\
\hline $\mathrm{pH}$ & & & 0.229 & $0.349^{*}$ \\
\hline extractable S & & & & $0.410^{* * *}$ \\
\hline \multicolumn{5}{|c|}{ Monarto Soil } \\
\hline$S$ oxidation & & $-0.673^{* *}$ & $0.354^{*}$ & $0.652^{* *}$ \\
\hline $\mathrm{pH}$ & & & $-0.328 \#$ & $-0.864^{* *}$ \\
\hline extractable $S$ & & & & $0.305 \#$ \\
\hline
\end{tabular}

be understood for sequential annual crops or perennial species management. ${ }^{37,38}$

Interestingly, $\mathrm{S}$ oxidation was not correlated with extractable $\mathrm{Zn}$ in the acid soil, whereas it was in the high-pH soil. Soil acidity is a very important factor related to $\mathrm{ZnO}$ dissolution and consequent increase in extractable $\mathrm{Zn}$ concentration in soil. .9,40 $^{3}$ Thus, the acidity that is generated by ES oxidation is only a small contributor to $\mathrm{Zn}$ dissolution from $\mathrm{ES}-\mathrm{Zn}$ fertilizer in soils that are already acidic. On the other hand, a significant correlation between ES oxidation and extractable $\mathrm{Zn}$ in the high-pH soil (Monarto) shows how important ES oxidation is for $\mathrm{ZnO}$ dissolution and diffusion from the granule in these soil conditions. This means that ES oxidation is more useful in 
increasing $\mathrm{Zn}$ availability in high-pH soils, which is an important observation for soil-specific $\mathrm{Zn}$ nutritional management. Additionally, comparison of the distribution of $\mathrm{Zn}$ across the soil sections showed little difference between the $\mathrm{ZnO}$ and $\mathrm{ZnSO}_{4}$ fertilizers (see Figures 3 and 4 and Table 4). This means that the low water solubility of $\mathrm{Zn}$ fertilizer in unbuffered laboratory tests underestimates potential $\mathrm{Zn}$ availability in acidic soils. On the other hand, soluble $\mathrm{Zn}$ fertilizer $\left(\mathrm{ZnSO}_{4}\right)$ provided higher $\mathrm{Zn}$ diffusion in the high-pH soil than the $\mathrm{ZnO}$ based fertilizers (Monarto soil, see Figures 3 and 4). This was also clear from the $\mathrm{CaCl}_{2}$-extractable $\mathrm{Zn}$, which was significantly higher in the 5-9 mm section for the $\mathrm{ZnSO}_{4}$ treatment than for the other treatments (see Table 4).

Soil $\mathrm{pH}$ is an important soil property in relation to $\mathrm{Zn}$ availability, and it is generally recognized as the main factor influencing $\mathrm{Zn}$ solubility and mobility across a wide range of soils. ${ }^{39,41,42}$ However, other factors also play important roles, such as organic matter content, ${ }^{43,44}$ type and content of clay minerals, ${ }^{45}$ and soil moisture. ${ }^{46}$ Zinc concentration and diffusion were much higher in the acidic Eneabba soil than in the slightly alkaline Monarto soil. When the soil $\mathrm{pH}$ was low and $\mathrm{S}$ oxidation contributed to a further $\mathrm{pH}$ reduction, $\mathrm{Zn}$ solubilization from oxide happened quickly, and it was free to diffuse through the soil, because adsorption is weak in acidic sandy soils. On the other hand, in the Monarto soil $\mathrm{Zn}$ solubilization from the oxide was limited by soil $\mathrm{pH}, \mathrm{S}$ oxidation was lower, and it was not enough to reduce soil $\mathrm{pH}$, except when $\mathrm{ES}-\mathrm{Zn}_{\text {thiooxidans }}$ was applied. In the $\mathrm{ES}-\mathrm{Zn}_{\text {thiooxidans }}$ treatment, the $\mathrm{Zn}$ concentration in the outer section was similar to that in the $\mathrm{ZnSO}_{4}$ treatment after 60 days, suggesting that $\mathrm{ZnO}$ was nearly fully solubilized after 60 days. This can be explained by the fact that only $0.35 \mathrm{mg}$ of $\mathrm{S}$ (or $2.5 \%$ of the $\mathrm{S}$ in the granule) needs to be oxidized to provide the acidity to oxidize the $\mathrm{Zn}$ present in the granule ( $0.7 \mathrm{mg}$ of $\mathrm{Zn}$ as $\mathrm{ZnO}$ ).

Although the autotrophic bacteria $A$. thiooxidans is the most important group of ES-oxidizing organisms, it is almost absent in most cropping soils. ${ }^{47}$ These observations suggest there could be benefits from applying ES-containing fertilizers inoculated with these microorganisms.

Our study shows a potential of $A$. thiooxidans inoculation of $\mathrm{ES}-\mathrm{Zn}$ for ES oxidation and consequently $\mathrm{pH}$ reduction even in a high-pH soil. However, additional research is needed to examine its real efficacy. On the other hand, we did not find enough evidence in this work to support the inclusion of A. niger in ES-Zn granules to increase ES oxidation in soil, although $A$. niger has been reported as an ES-oxidizing microrganism. ${ }^{21,48,49}$

The inoculation of ES-oxidizing microorganisms in fertilizers should explore the survival capacity over time because it is a key requirement for inoculated fertilizer production and efficacy when applied. Whrease $A$. niger survived in fertilizer granules for at least 4 months (data not shown), we could not evaluate with accuracy how long the $A$. thiooxidans survived in ES-Zn fertilizer granules at a range of temperatures.

Results for the addition of 5\% sugar to increase ES oxidation in ES-Zn fertilizers were inconclusive. Adding a labile carbon may promote the activity of heterotrophic S-oxidizing microorganisms in soil. ${ }^{22,50}$ Growth of S-oxidizing microorganisms around or inside the granules can increase the contact area to ES particles and accelerate its oxidation in soil. It is possible that general heterotrophic microorganisms in these low organic carbon soils may have outcompeted the S-oxidizers, and thus no measurable benefit in S-oxidation was observed by adding glucose. Future tests using different soils and higher sugar formulations should be undertaken to examine the effects of sugar in ES-Zn fertilizers. In addition, a plant growth test is needed to evaluate $S$ and $Z n$ uptake over time and measure the efficiency of co-granulated $\mathrm{Zn}-\mathrm{ES}$ fertilizers.

This work demonstrates that ES-Zn granular fertilizers can be effective for soil application, given that both $\mathrm{S}$ and $\mathrm{Zn}$ concentrations increased in soil over time. Compared to $\mathrm{ZnO}$ only, elemental $\mathrm{S}-\mathrm{Zn}$ application in a sandy acidic soil increased both $\mathrm{S}$ and $\mathrm{Zn}$ concentrations and diffusion of $\mathrm{Zn}$ away from the point of application, similar to soluble $\mathrm{Zn}-$ sulfate fertilizers. The ES-Zn application in a slightly alkaline soil increased $\mathrm{S}$ and $\mathrm{Zn}$ concentration more slowly than in the acidic soil. We did not find enough evidence to support the addition of sugar or inoculation with $A$. niger to increase ES oxidation. Although early ES oxidation was increased by adding the ES-oxidizing bacterium $A$. thiooxidans, the results were not conclusive in terms of its efficacy in ES fertilizers.

\section{AUTHOR INFORMATION}

\section{Corresponding Author}

*(E.M.M.) E-mail: mattiello@ufv.br. ORCID

Edson M. Mattiello: 0000-0001-7872-5659

\section{Funding}

This work was supported by funding from Coordination for Scientific Support for Post-Doctoral Level Training - CAPESBEX 1562/14-2, Brazil.

\section{Notes}

The authors declare no competing financial interest.

\section{ACKNOWLEDGMENTS}

We thank Dr. Richard Bell and Bob Gilkes for their useful review and suggestions. We also thank Colin Rivers, Bogumila Tomczak, Ashleigh Broadbent. and Evelina Facelli for analyses and technical assistance and the Mosaic Co. for infrastructure support.

\section{REFERENCES}

(1) Scherer, H. W. Sulphur in crop production - invited paper. Eur. J. Agron. 2001, 14, 81-111.

(2) Cakmak, I. Enrichment of cereal grains with zinc: agronomic or genetic biofortification? Plant Soil 2008, 302, 1-17.

(3) Wei, Y.; Shohag, M. J. I.; Wang, Y.; Lu, L.; Wu, C.; Yang, X. Effect of zinc sulfate fortification in germinated brown rice on seed zinc concentration, bioavailability, and seed germination. J. Agric. Food Chem. 2012, 60, 1871-1879.

(4) Cakmak, I.; Ekiz, H.; Yilmaz, A.; Torun, B.; Köleli, N.; Gültekin, I.; Alkan, A.; Eker, S. Differential response of rye, triticale, bread and durum wheats to zinc deficiency in calcareous soils. Plant Soil 1997, $188,1-10$.

(5) Hacisalihoglu, G.; Ozturk, L.; Cakmak, I.; Welch, R. M.; Kochian, L. Genotypic variation in common bean in response to zinc deficiency in calcareous soil. Plant Soil 2004, 259, 71-83.

(6) Akay, A. Effect of zinc fertilizer applications on yield and element contents of some registered chickpeas varieties. Afr. J. Biotechnol. 2013, 10, 12890-12896.

(7) Germida, J. J.; Janzen, H. H. Factors affecting the oxidation of elemental sulfur in soils. Fert. Res. 1993, 35, 101-114.

(8) Donald, D.; Chapman, S. J. Use of powdered elemental sulphur as a sulphur source for grass and clover. Commun. Soil Sci. Plant Anal. 1998, 29, 1315-1328.

(9) Rothbaum, H. P.; Groom, P. S. Fire hazards in the use of fertilisers containing elemental sulphur. New J. Sci. 1961, 4, 476-488. 
(10) Zhao, C.; Degryse, F.; Gupta, V.; McLaughlin, M. J. Elemental sulfur oxidation in Australian cropping soils. Soil Sci. Soc. Am. J. 2015, 79, 89-96.

(11) Janzen, H. H.; Bettany, J. R. Measurement of sulfur oxidation in soils. Soil Sci. 1987, 143, 444-452.

(12) Dick, R. P.; Deng, S. Multivariate factor analysis of sulfur oxidation and rhodanese activity in soils. Biogeochemistry 1991, 12, 87-101.

(13) Janzen, H. H.; Bettany, J. R. The effect of temperature and water potential on sulfur oxidation in soils. Soil Sci. 1987, 144, 81-89.

(14) Lee, A.; Watkinson, J. H.; Lauren, D. R. Factors affecting oxidation rates of elemental sulphur in a soil under a ryegrass dominant sward. Soil Biol. Biochem. 1988, 20, 809-816.

(15) Lettl, A.; Langkramer, O.; Lochman, V. Dynamics of oxidation of inorganic sulphur compounds in upper soil horizons of spruce forests. Folia Microbiol. (Dordrecht, Neth.) 1981, 26, 24-28.

(16) Grayston, S. J.; Germida, J. Sulfur-oxidizing bacteria as plant growth promoting rhizobacteria for canola. Can. J. Microbiol. 1991, 37, $521-529$.

(17) Suzuki, I.; Chan, C.; Takeuchi, T. Oxidation of elemental sulfur to sulfite by Thiobacillus thiooxidans cells. Appl. Environ. Microbiol. 1992, 58, 3767-3769.

(18) Yang, Z.-H.; Stoven, K.; Haneklaus, S.; Singh, B. R.; Schnug, E. Elemental sulfur oxidation by Thiobacillus spp. and aerobic heterotrophic sulfur-oxidizing bacteria. Pedosphere 2010, 20, 71-79.

(19) McCaskill, M. R.; Blair, G. J. Particle size and soil texture effects on elemental sulfur oxidation. 1. Agron. J. 1987, 79, 1079.

(20) Chapman, S. J. Thiobacillus populations in some agricultural soils. Soil Biol. Biochem. 1990, 22, 479-482.

(21) Grayston, S. J.; Wainwright, M. Fungal sulphur oxidation: effect of carbon source and growth stimulation by thiosulphate. Trans. Br. Mycol. Soc. 1987, 88, 213-219.

(22) Lawrence, J. R.; Germida, J. J. Microbial and chemical characteristics of elemental sulfur beads in agricultural soils. Soil Biol. Biochem. 1991, 23, 617-622.

(23) Eow, J. S. Recovery of sulfur from sour acid gas: a review of the technology. Environ. Prog. 2002, 21, 143-162.

(24) Messick, D.; Fan, M.; Brey, C. Global sulfur requirement and sulfur fertilizers. Landbauforsch. Voelkenrode 2005, 283, 97.

(25) Messick, D.; Brey, C.; Fan, M. Sulphur Sources, Their Processing and Use in Fertiliser Manufacture; International Fertiliser Society: York, UK, 2002.

(26) Mortvedt, J. J. Crop response to level of water-soluble zinc in granular zinc fertilizers. Fert. Res. 1992, 33, 249-255.

(27) McBeath, T. M.; McLaughlin, M. J. Efficacy of zinc oxides as fertilisers. Plant Soil 2014, 374, 843-855.

(28) Borichewski, R. M.; Umbreit, W. W. Growth of Thiobacillus thiooxidans on glucose. Arch. Biochem. Biophys. 1966, 116, 97-102.

(29) McClelland, R. Gram's stain: the key to microbiology. MLO, Med. Lab. Obs. 2001, 33, 20-22.

(30) Isbell, R. F. The Australian Soil Classification; CSIRO Publishing: Melboune, Australia, 2002.

(31) Degryse, F.; Baird, R.; McLaughlin, M. J. Diffusion and solubility control of fertilizer-applied zinc: chemical assessment and visualization. Plant Soil 2015, 386, 195-204.

(32) Ketterings, Q.; Miyamoto, C.; Mathur, R. R.; Dietzel, K.; Gami, S. A Comparison of soil sulfur extraction methods. Soil Sci. Soc. Am. J. 2011, 75, 1578.

(33) Watkinson, J.; Lee, A.; Lauren, D. Measurement of elemental sulfur in soil and sediments - field sampling, sample storage, pretreatment, extraction and analysis by high performance liquid chromatography. Aust. J. Soil Res. 1987, 25, 167-178.

(34) SAS Institute Inc. Statistical Analysis System, 1st ed.; SAS: Cary, NC, USA, 2003.

(35) Slaton, N. A.; Norman, R. J.; Wilson, C. E. Effect of zinc source and application time on zinc uptake and grain yield of flood-irrigated rice. Agron. J. 2005, 97, 272-278.
(36) Degryse, F.; Ajiboye, B.; Baird, R.; da Silva, R. C.; McLaughlin, M. J. Oxidation of elemental sulfur in granular fertilizers depends on the soil-exposed surface area. Soil Sci. Soc. Am. J. 2016, 80, 294.

(37) Slaton, N. A.; Norman, R. J.; Gilmour, J. T. Oxidation rates of commercial elemental sulfur products applied to an alkaline silt loam from Arkansas. Soil Sci. Soc. Am. J. 2001, 65, 239-243.

(38) Degryse, F.; Ajiboye, B.; Baird, R.; da Silva, R. C.; McLaughlin, M. J. Availability of fertiliser sulphate and elemental sulphur to canola in two consecutive crops. Plant Soil 2016, 398, 313-325.

(39) Lindsay, W. Zinc in soils and plant nutrition. Adv. Agron. 1972, 24, 147-181.

(40) Wu, X.; Aasen, I. Models for predicting soil zinc availability for barley. Plant Soil 1994, 163, 279-285.

(41) Sauvé, S.; Hendershot, W.; Allen, H. E. Solid-solution partitioning of metals in contaminated soils: dependence on $\mathrm{pH}$, total metal burden, and organic matter. Environ. Sci. Technol. 2000, 34, $1125-1131$.

(42) Casagrande, J. C.; Soares, M. R.; Mouta, E. R. Zinc adsorption in highly weathered soils. Pesqui. Agropecu. Bras. 2008, 43, 131-139.

(43) Fan, T.-T.; Wang, Y.-J.; Li, C.-B.; He, J.-Z.; Gao, J.; Zhou, D.-M.; Friedman, S. P.; Sparks, D. L. Effect of organic matter on sorption of $\mathrm{Zn}$ on soil: elucidation by wien effect measurements and EXAFS spectroscopy. Environ. Sci. Technol. 2016, 50, 2931-2937.

(44) Degryse, F.; Smolders, E. Mobility of Cd and $\mathrm{Zn}$ in polluted and unpolluted Spodosols. Eur. J. Soil Sci. 2006, 57, 122-133.

(45) Ghiri, M. N.; Rezaei, M.; Sameni, A. Zinc sorption-desorption by sand, silt and clay fractions in calcareous soils of Iran. Arch. Agron. Soil Sci. 2012, 58, 945-957.

(46) Warncke, D. D.; Barber, S. A. Diffusion of zinc in soil: I. The influence of soil moisture. Soil Sci. Soc. Am. J. 1972, 36, 39-42.

(47) Zhao, C.; Gupta, VV. S. R.; Degryse, F.; McLaughlin, M. Abundance and diversity of sulphur-oxidising bacteria and their role in oxidizing elemental sulphur in cropping soils. Biol. Fertil. Soils 2017, 53, $159-169$.

(48) Grayston, S. J.; Nevell, W.; Wainwright, M. Sulphur oxidation by fungi. Trans. Br. Mycol. Soc. 1986, 87, 193-198.

(49) Shinde, D.; Patil, P.; Patil, B. Potential use of sulphur oxidizing microorganism as soil inoculant. Crop Res. 1996, 11, 291-295.

(50) Wainwright, M.; Nevell, W.; Grayston, S. J. Effects of organic matter on sulphur oxidation in soil and influence of sulphur oxidation on soil nitrification. Plant Soil 1986, 96, 369-376. 